\title{
Models of Propagation of Inside Information
}

\author{
A.A. BAKLARZ ${ }^{a, *}$ J. Bogusz ${ }^{b}$ And C.B. MARTYsZ ${ }^{c}$ \\ ${ }^{a}$ Polska Agencja Nadzoru Audytowego, ul. Kolejowa 1, PL 01217 Warsaw, Poland \\ ${ }^{b}$ TUiR Allianz Polska S.A., ul. Rodziny Hiszpańskich 1, PL 02685 Warsaw, Poland \\ ${ }^{c}$ Warsaw School of Economics, Institute of Finance, \\ ul. Madalińskiego 6/8, PL 02513 Warsaw, Poland
}

Doi: 10.12693/APhysPolA.138.7 *e-mail: agnieszka.baklarz@pana.gov.pl

\begin{abstract}
Insider trading is the buying or selling of a publicly traded company's stock by someone who has non-public, material information about that stock. The following article presents an innovative model which could help to solve the major problem of effective detection of insider trading. According to our research, the simultaneous occurrence of an increased volume and price changes without the occurrence of other disturbing factors (e.g., earlier company reports) allows to strongly suspect the occurrence of insider trading. This means that a significant increase in transaction volume is a better indicator of the likely insider trading than a price change alone. By analysing the disclosed case of insider trading on Drewex shares in 2010 we tested the effectiveness of our model and we came to the conclusion that the probability of insider trading in Drewex SA shares was $70 \%$.
\end{abstract}

topics: insider trading, information propagation model, market abuse, financial market, stock exchange

\section{Introduction}

Insider trading is defined as a transaction carried out on the stock exchange on the basis of inside information. Insider Trading is widely regarded as illegal because it is contrary to the principle of equal access of investors to information. In the relatively short 28-year history of the Warsaw Stock Exchange (WSE) there were just 11 cases insider trading conviction.

In October 2018, PawełNarkiewicz was convicted for insider trading, which took place between October and November 2010. The description of this insider trading case has received wide coverage in the press and has revealed one of the mechanisms of insider trading. From the point of view of modelling the propagation of information, this case provides a valuable lesson in as many as 3 various examples from a similar period of time. The convergence of the method of operation allows for the preparation of a model of propagation of information and a short-term increase in the share price and then the transition to the equilibrium price. This research shows that significant increase in transaction volume is a better indicator of the insider trading than just a change in price.

\section{Definition of inside information}

Without inside information, insider trading would not exist. In European law, inside information is defined in art. 7 of MAR. The classification of a given information as inside is decided by the issuer of securities, who is obliged to immediately make it public or (in justified cases) to delay making it public. In a company that correctly performs information obligations arising, inter alia, from MAR, there should be no inside information. The creation of inside information depends on four elements:

- The information is confidential and has not been made public.

- There is a relationship between the information and the issuer or financial instrument.

- The information is potentially price-creating, i.e., it may affect the value or price of financial instruments or related derivatives.

- The information is precise, i.e., it is possible to deduce from it the possible impact on the prices of financial instruments or related derivatives.

\section{Definition of an insider}

In order to better understand insider trading, it is worth to characterize the people who perform this practice. Insider is a person who, thanks to inside information, has better, more accurate knowledge about the value of a financial instrument [1]. The position or function is irrelevant here - anyone who possesses inside information will be called the insider. This does not mean, however, that every insider is a criminal, as only the use or transfer of inside information in an unauthorized manner is punishable. Insiders are generally not so-called astute investors, i.e., people who are experienced and 
have extensive knowledge, who based on publicly available facts, gossips and rumours, their own experience and the context that gives them direction to create inside information using the synergy of acquired resources (in accordance with the so-called mosaic theory). This means that the same valuable information can be obtained both illegally (e.g., as a result of theft or transfer of information by an employee of the issuer) and legally (e.g., analytically using multiple sources of knowledge) which is always at risk of uncertainty.

We divide insiders into primary insiders and secondary insiders. Primary insiders are somehow related to the issuer to whom the information relates, while secondary insiders obtain inside information as a result of contact with primary insiders [2] A classic example of a secondary insider is the so-called tippee who receives the information in order to be able to use it for his own benefit. The secondary insider is also the person who obtained inside information as a result of an intentional crime (criminal insider). We also distinguish the accidental insider who receives the information without knowingly contacting the person disclosing the information (e.g., overheard a conversation in a restaurant).

\section{Definition of insider trading}

The expression insider trading comes from American terminology and means any form of stock trading based on material non-public information [3]. In European law, insider trading is understood as the unauthorized use or disclosure of inside information, as well as making a recommendation based on it, cancelling or changing an order regarding a financial instrument (if such order was made before acquiring inside information) or inducing others to do the above.

Pursuant to Regulation (EU) no 596/2014 of the European Parliament and of the Council of 16 April, 2014 (MAR) [4], the use of inside information consists in the purchase, sale of financial instruments or any other legal act that may result in the disposal of such instruments, which is based on inside information on one's own account or of a third party's. The use of inside information is also the cancellation or modification of an order relating to the financial instrument to which this information relates, if the order was placed before the person concerned acquired the inside information. In turn, disclosure of inside information is the transmission, enabling or facilitating the entry into possession of inside information by an unauthorized person.

The prohibition of insider dealing and of unlawful disclosure of inside information results from art. 14 of MAR. It is also prohibited to make any recommendations or induce others to acquire, sell, cancel or change the order based on inside information regarding the financial instrument to which this inside information relates, provided that such persons know or should know that they operate on the basis of inside information (MAR, art. 8). However, there are legitimate behaviours that are not perceived as insider trading, including inter alia: (MAR, art. 9):

- execution of orders on behalf of third parties in a legitimate manner $(. .$.$) ,$

- performance of a contract concluded prior to obtaining inside information,

- using knowledge of your own decision to buy or sell financial instruments,

- disclosure in connection with employment or occupation duties,

- market sounding (MAR, art. 11).

The prohibition of insider trading in European law applies to financial instruments indicated in art. 2 paragraph 1 of MAR and transactions related to these instruments, pursuant to art. 2 paragraphs 3 and 4 of MAR. It is worth emphasizing that the prohibitions and requirements set out in the MAR apply to acts and omissions in the EU and in third countries, provided that these acts or omissions relate to the financial instruments referred to in art. 2 of MAR. The provisions of MAR, therefore, apply inter alia to financial instruments [5]:

- admitted to trading on a regulated market, on multilateral trading facilities (MTFs), or being the subject of an application for admission to trading on those markets,

- traded on organized trading platforms (OTF),

- other than those indicated above, the price or value of which depend on the price or value of the financial instruments indicated above (e.g. derivatives, swaps, contracts for differences, etc.).

\section{The insider trading scheme}

Acquiring inside information creates an illegal asymmetry of information between the insider and the market. The success of insider trading, i.e., achieving a certain financial benefit, is conditioned by the use of this asymmetry before the information becomes public. In practice, insider trading involves the purchase (in case of good information) or sale (in case of bad information) by the insider of a financial instrument before the related inside information is made public.

There are two main reasons for disclosing inside information to secondary insiders. First, primary insiders may intentionally refrain from entering into transactions on their own account due to the fact that their stock operations are subject to strict supervision or reporting (MAR, art. 19) or may not be concluded at all, e.g., due to contractual restrictions, or the so-called closed periods (MAR, art. 11-12). Secondly, the benefits of 


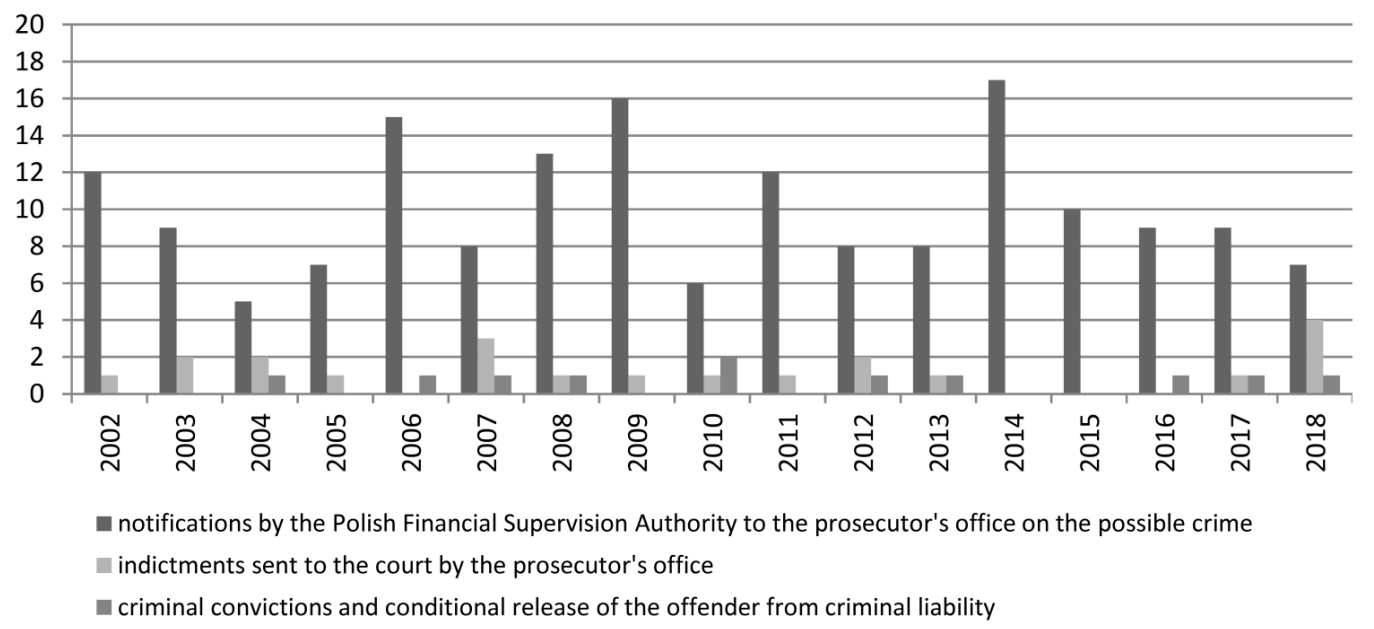

Fig. 1. Disclosure or use of inside information in Poland (art. 180 and art. 181 of the Act on trading of fin. instr.) Source: Annual reports of the Polish Financial Supervision Authority and the Polish Securities and Stock Exchange Commission [6].

the unauthorized use of inside information are compounded by the capital involved in the process the larger it is, the higher the potential profits from insider trading. Hence, it may be more profitable for the primary insider to disclose inside information to the secondary insider (e.g., a wealthy colleague or fund manager), in exchange for, for example, a portion of the transaction profit, than to enter into such transactions on his own account. The aspect of confidentiality and impeded detectability is not without significance here, as establishing links between the primary and secondary insiders can be problematic, thus hindering the effective detection of insider trading and punishing its perpetrators.

Difficulties in effective sanctioning insider trading on the Polish capital market are illustrated in Fig. 1. In the period 2002-2018, out of 171 notifications of the Polish Financial Supervision Authority to the prosecutor's office of suspected crime of disclosing or using inside information only in 21 cases $(12 \%)$ indictments were formulated and only in 11 cases ( $6 \%$ of notifications) convictions were issued.

Transactions based on inside information are usually concluded a few days before this information is made public. In the case of the best-researched American market, P. Augustin, M. Brenner and M.G. Subrahmanyam, on the basis of 1859 mergers and acquisitions from 1996-2012, stated that even $25 \%$ of M\&A transactions were preceded by positive, extraordinary (i.e., excluding randomness) turnover on share options of the acquired company, although US SEC supervision only suspected in $5 \%$ of transactions [7]. In turn, L. Meulbroek, examining the transactions of 320 people accused by the SEC for insider trading in 1980-1989, in $81 \%$ of cases observed an increase in share prices ahead of official announcements, which was triggered by insider transactions and intensified after the disclosure of inside information [8].
One of the best documented examples of insider trading in Poland is the case of Pawel Narkiewicz $(\mathrm{PN}), \mathrm{CEO}$ of the Calavatra Capital (CC) investment boutique, sentenced on 27 April 2018 to PLN 80,000 fine and forfeiture of part of the illegally obtained financial gain (PLN 12,300) for the events of October and November 2010 (IV K 275/17). PN disclosed multiple inside information to his friend Robert Boruszewski (RB), concerning CC's future investments in Techmex SA, PC Guard SA and Drewex SA, urged RB to buy shares of these companies and then to sell them for profit due to increases in exchange rates caused by the release of current reports by these companies as shown in Table I. Evidence in the case were, among others, telephone bills proving that $\mathrm{PN}$ and RB talked to each other many times on the days covered by the indictment, and the history of RB's brokerage account and PN's bank accounts — payments to RB's brokerage account were correlated with cash withdrawals made by PN. The illegal transactions started a few days before the release of current reports, as shown in Table II (purchase transactions concluded after release of the reports were omitted).

TABLE I

Insider trading on the shares of Techmex SA, PC Guard SA and Drewex SA. Source: Judgment of the District Court for Warszawa Wola in Warszawa at the Fourth Criminal Division of 27 April 2018, IV K $275 / 17$ [6].

\begin{tabular}{c|l|l}
\hline $\begin{array}{c}\text { Company } \\
\text { Name }\end{array}$ & \multicolumn{1}{|c|}{$\begin{array}{c}\text { Time of purchase } \\
\text { of shares } \\
\text { by insider }(\mathrm{RB})\end{array}$} & $\begin{array}{l}\text { Current report } \\
\text { release date }\end{array}$ \\
\hline \hline Techmex SA & $\begin{array}{l}21.10 .2010 \\
\text { at } 11: 54-15: 05\end{array}$ & $\begin{array}{l}21.10 .2010 \\
\text { at } 15: 32\end{array}$ \\
\hline PC Guard SA & $16.11 .2010,17.11 .2010$ & $\begin{array}{l}18.11 .2010 \\
\text { at } 15: 22\end{array}$ \\
\hline Drewex SA & $\begin{array}{l}26.10 .2010,4.11 .2010, \\
12.11 .2010\end{array}$ & $\begin{array}{l}11.11 .2010 \\
\text { at } 17: 05\end{array}$ \\
\hline
\end{tabular}




\begin{tabular}{|c|c|c|c|c|c|c|c|c|c|c|c|c|c|c|c|c|c|}
\hline$\stackrel{N}{*}$ & $\stackrel{\sim}{\stackrel{v}{\sigma}}$ & $\overrightarrow{0}$ & $\overrightarrow{\dot{c}}$ & $\stackrel{\dot{d}}{\dot{d}}$ & $\stackrel{\odot}{\dot{\phi}}$ & $\stackrel{\overrightarrow{\dot{c}}}{\vec{c}}$ & $\stackrel{\bullet}{\dot{c}}$ & $\stackrel{\bullet}{\vec{\rho}}$ & $\stackrel{\bullet}{\dot{r}}$ & $\stackrel{\Gamma}{\dot{\sigma}}$ & $\stackrel{\bullet}{v}$ & $\stackrel{\bullet}{\vec{c}}$ & $\bullet$ & $\stackrel{\bullet}{\stackrel{i}{N}}$ & $\stackrel{\bullet}{\stackrel{\oplus}{v}}$ & $\stackrel{\bullet}{\vec{r}}$ & Opening rate \\
\hline  & $\begin{array}{l}0 \\
\dot{\infty}\end{array}$ & $\stackrel{N}{\mathcal{U}}$ & $\stackrel{\sqcup}{0}$ & $\stackrel{\vec{\sigma}}{\dot{\sigma}}$ & $\stackrel{\bullet}{8}$ & $\stackrel{v}{v}$ & $\stackrel{\bullet}{\dot{c}}$ & $\stackrel{\vec{\sigma}}{\vec{i}}$ & $\ddot{g}$ & $\stackrel{\dot{g}}{\circ}$ & $\bullet$ & $\stackrel{\sqcup}{\vec{c}}$ & $\begin{array}{l}N \\
\stackrel{0}{0}\end{array}$ & $\stackrel{\bullet}{\triangleright}$ & $\stackrel{\vec{\Delta}}{\stackrel{\vec{v}}{*}}$ & $\stackrel{\bullet}{\vec{c}}$ & Ceiling rate \\
\hline$\stackrel{\sim}{5}$ & $\stackrel{\sim}{\stackrel{\infty}{\infty}}$ & $\overrightarrow{0}$ & 灾 & $\dot{\sigma}$ & $\dot{\sigma}$ & $\stackrel{\bullet}{\dot{c}}$ & 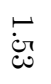 & 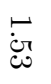 & $\stackrel{\bullet}{\dot{r}}$ & $\stackrel{\bullet}{\dot{\theta}}$ & $\dot{\sigma}$ & $\stackrel{\bullet}{\dot{\theta}}$ & $\stackrel{\odot}{\dot{c}}$ & $\stackrel{\bullet}{\stackrel{\vec{N}}{*}}$ & $\breve{\dot{\omega}_{\infty}}$ & $\stackrel{\vec{\perp}}{\stackrel{\vec{\perp}}{ }}$ & Minimum rate \\
\hline 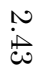 & $\stackrel{\sim}{\stackrel{\sim}{\infty}}$ & 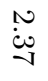 & $\stackrel{\bullet}{\vec{y}}$ & $\dot{\sigma}$ & $\stackrel{\bullet}{\dot{\omega}}$ & $\stackrel{\bullet}{\dot{\sigma}}$ & $\stackrel{\bullet}{\vec{c} \pi}$ & •্ं & $\stackrel{\vec{s}}{\dot{s}}$ & $\stackrel{\bullet}{\dot{\sigma}}$ & $\stackrel{\bullet}{\dot{\sigma}}$ & $\ddot{\dot{c}}$ & 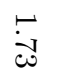 & $\stackrel{\varpi}{\triangleright}$ & 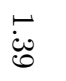 & 宫 & Closing rate \\
\hline$\stackrel{\rightleftarrows}{\doteqdot}$ & 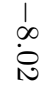 & نَّ & $\begin{array}{l}\dot{0} \\
\dot{0}\end{array}$ & $\stackrel{1}{i}$ & $\stackrel{\oplus}{\oplus}$ & cir & $\stackrel{+}{\stackrel{1}{ \pm ் ~}}$ & $\underset{⿱ 亠 䒑}{+}$ & $\stackrel{\infty}{\infty}$ & $\begin{array}{l}1 \\
\dot{\omega} \\
\dot{\phi}\end{array}$ & $\ddot{i}$ & $\begin{array}{l}1 \\
\stackrel{1}{c} \\
\dot{\infty}\end{array}$ & $\begin{array}{l}1 \\
0 \\
\dot{g} \\
y\end{array}$ & $\begin{array}{l}\stackrel{N}{\sim} \\
\dot{\infty}\end{array}$ & $\stackrel{+}{\stackrel{1}{\not}}$ & $\begin{array}{l}1 \\
0 \\
0 \\
0 \\
-1\end{array}$ & $\%$ change of rate \\
\hline $\begin{array}{l}\text { J } \\
\text { v } \\
\text { U } \\
\text { I }\end{array}$ & $\begin{array}{l}0 \\
\mathbb{N} \\
\mathbb{N} \\
\infty \\
\stackrel{\mathbb{N}}{N}\end{array}$ & $\begin{array}{l}\underset{\text { J }}{J} \\
0 \\
0 \\
\infty \\
\infty\end{array}$ & 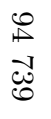 & $\begin{array}{l}\mathbb{N} \\
\mathbb{B}\end{array}$ & $\begin{array}{l}\text { D } \\
\mathbb{0} \\
\overrightarrow{0}\end{array}$ & $\begin{array}{l}\text { जै } \\
\S \\
\varnothing\end{array}$ & $\begin{array}{l}\mathcal{N} \\
\mathcal{G} \\
\stackrel{D}{\leftarrow}\end{array}$ &  & $\begin{array}{l}\text { N } \\
\text { c } \\
\text { U. }\end{array}$ & 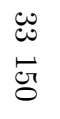 & $\begin{array}{l}\vec{\omega} \\
\infty \\
\stackrel{\infty}{-}\end{array}$ & $\begin{array}{l}\vec{J} \\
0 \\
0 \\
0\end{array}$ & 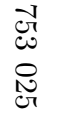 & $\begin{array}{l}\underbrace{}_{\infty} \\
\stackrel{\infty}{\perp} \\
\infty \\
\infty\end{array}$ & 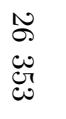 & $\begin{array}{l}\vec{\infty} \\
\vec{\infty}\end{array}$ & Trading volume [pcs.] \\
\hline v & $\stackrel{\Xi}{\Xi}$ & 蛇 & 官 & $\stackrel{\ominus}{\bullet}$ & g & $\stackrel{\infty}{\infty}$ & $\stackrel{c}{\omega}$ & 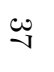 & ن & $\stackrel{\oplus}{v}$ & $\stackrel{g}{v}$ & Б̆ & $\underset{\infty}{\infty}$ & 灾 & $\stackrel{0}{0}$ & ๑ & Number of transactions \\
\hline 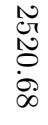 & $\begin{array}{l}\stackrel{D}{\infty} \\
\stackrel{D}{V} \\
⺊\end{array}$ & $\begin{array}{c}\stackrel{N}{N} \\
\underset{N}{+} \\
\stackrel{\infty}{*}\end{array}$ & 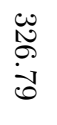 & $\begin{array}{l}\text { 定 } \\
\text { is }\end{array}$ & $\begin{array}{l}\overrightarrow{8} \\
8 \\
\dot{\infty}\end{array}$ & $\begin{array}{l}\stackrel{N}{\oplus} \\
\stackrel{\oplus}{\dot{\theta}} \\
\dot{c}\end{array}$ & $\begin{array}{l}\text { రै } \\
\dot{\sigma}\end{array}$ & 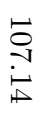 & نै & $\begin{array}{l}\overrightarrow{8} \\
\stackrel{8}{0} \\
-10\end{array}$ & 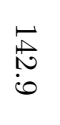 & 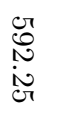 & 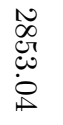 & 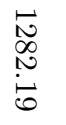 & $\stackrel{⿱ 乛}{\stackrel{\infty}{\infty}}$ & 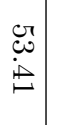 & $\begin{array}{l}\text { Turnover value } \\
\text { (in thousands) }\end{array}$ \\
\hline 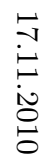 & 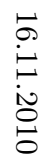 & 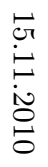 & 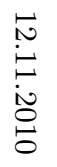 & 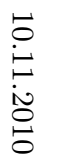 & $\begin{array}{l}\stackrel{8}{0} \\
\dot{ت} \\
\dot{0} \\
\stackrel{0}{0} \\
0\end{array}$ & $\begin{array}{l}\stackrel{8}{\infty} \\
\stackrel{0}{ت} \\
\stackrel{0}{0} \\
\stackrel{0}{0}\end{array}$ & 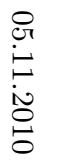 & 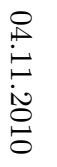 & 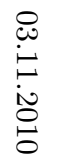 & $\begin{array}{l}\stackrel{̊}{0} \\
\stackrel{\sim}{ت} \\
\stackrel{0}{0} \\
\stackrel{0}{0}\end{array}$ & $\begin{array}{l}0 \\
\stackrel{0}{0} \\
\stackrel{0}{0} \\
\dot{0} \\
0 \\
0\end{array}$ & 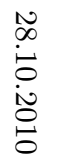 & $\begin{array}{l}\stackrel{N}{N} \\
\stackrel{\sim}{0} \\
\stackrel{0}{0} \\
\stackrel{0}{0} \\
0\end{array}$ & 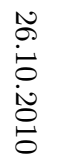 & 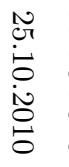 & 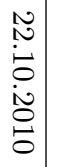 & Date \\
\hline త్ర & $\stackrel{\infty}{\stackrel{\infty}{\infty}}$ & $\stackrel{\overrightarrow{0}}{8}$ & 总 & $\begin{array}{l}\text { ] } \\
\text { ] }\end{array}$ & 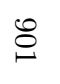 & $\stackrel{\infty}{N}$ & స్త్ & $\underset{c}{\mathscr{C}}$ &  & Ō & $\underset{\oplus}{\stackrel{g}{\oplus}}$ & $\underset{\infty}{\stackrel{\varpi}{\infty}}$ & $\underset{\infty}{\rightleftarrows}$ & U̦ & $\begin{array}{l}\infty \\
-1 \\
\infty\end{array}$ & $\begin{array}{l}0 \\
8 \\
0\end{array}$ & $\begin{array}{l}\text { Average } \\
\text { transaction value }\end{array}$ \\
\hline نَّ & $\underset{⿱ 亠 凶}{\dot{\infty}}$ & $\stackrel{c r}{\sqcup}$ & $\stackrel{\varphi}{\sqcup}$ & $\overrightarrow{0}$ & No & $\stackrel{\infty}{\infty}$ & $\begin{array}{l}\stackrel{N}{N} \\
\dot{N}\end{array}$ & مِ & $\stackrel{N}{N}$ & $\stackrel{i}{i N}$ & $\stackrel{N}{\stackrel{N}{\omega}}$ & $\underset{v}{\dot{\omega}}$ & $\stackrel{⿱}{\stackrel{\Delta}{v}}$ & $\stackrel{\vec{i}}{i}$ & $\stackrel{n}{\stackrel{n}{a}}$ & $\begin{array}{l}N \\
\dot{g} \\
\dot{v}\end{array}$ & $\begin{array}{l}\text { Average } \\
\text { transaction value }\end{array}$ \\
\hline
\end{tabular}

N N N N N N N

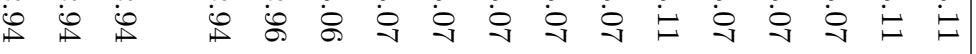
of a 60 day transaction

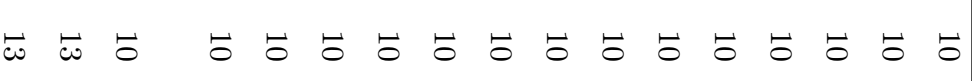
Median number

\begin{tabular}{|c|}
\hline$F 00$ \\
\hline
\end{tabular}
of transactions of 60 days Эิ

Median volume

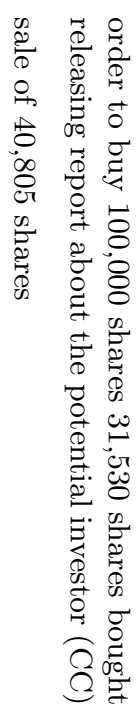

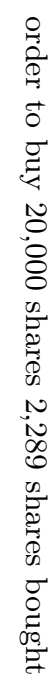

0
0
0
0
0
0
0
0
0
0
8
0
0
0
0
0
0
0
0
0
0
0
0
0
0
0
0
00
0

Remarks 


\subsection{Description of the cases studied}

In all 3 cases, the insider trading pattern was identical. PN, as a representative of the Calatrava Capital (CC) investment boutique, held discussions with the boards of listed companies (Techmex, PC Guard, Drewex) or key shareholders of these companies on the potential purchase of shares in these companies by CC. These conversations were confidential. If the negotiations had been successful and if CC had become an investor in one of these companies, the share price of these companies could have increased significantly. Due to the potential importance of such information for the value of shares, each company was required to disclose such information to the public. The relevant current report was released, but slightly later than the idea for CC's investment in a specific company originated. When the negotiations were already well advanced and heading for the final, PN made telephone calls to $\mathrm{RB}$ and, as a result of these conversations, orders were placed to buy shares of each of these companies. Immediately a day after the release of the conversation report (the next day or the following days), RB started to sell those shares. In further analysis, we will focus on the case of Drewex due to the occurrence of a significant discrepancy in time between the use of inside information and the date of the communication.

Table II presents Drewex's quotations for the transaction period based on inside information. The median number of transactions from 60 days performed on Drewex shares during the observed period was only 10 transactions with a median value between PLN 2.94 thousand and 3.11 thousand. The median transaction volume in the last 60 days was between 8,000 and 9,000 shares.

On the day of the first transaction carried out by RB, he placed an order to buy shares for PLN 36 thousand, but only an order for nearly 7 thousand shares was made [9] probably due to the price set too low. On that day, however, the volume amounted to over 384,000 shares, which is over 40 times more than the median and nearly 55 times more than the order to buy of RB. At the same time, the average transaction value increased by as much as $38 \%$ compared to the median. What is important, the stock exchange indices on the WSE did not record any particular changes in turnover and Drewex did not provide any other announcements.

A simple conclusion that can be drawn from the (relatively) small order of RB to buy in relation to the volume on a given day indicates the possibility of more extensive disclosure of inside information than it was proven. Hence, it is worth considering the hypothesis that there were more insider traders than the disclosed RB.

\section{Information propagation model}

To confirm the above hypothesis fully, let's consider models for the propagation of inside information. In the flow of inside information there are



Fig. 2. An illustrative network of information flow between secondary and primary insiders. Source: Unpublished doctoral thesis A. Baklarz [10].

at least two groups of people between whom there should be no flow of information until it is officially disclosed. The first is a group of corporate insiders (primary insider traders) who have access to information - this is a constant group of people (not growing in a short period) limited by internal procedures. This group includes people from the management board, senior and middle management, advisers and regular employees involved in processing this information. In the case described above the PN is a primary insider.

The second group consists of people who do not have direct access to inside information and are outside the company (secondary insider traders). This group can be a growing group of (potential) investors but In a short period of time it can be assumed that such a group is also a non-growing. When analysing the flow of inside information, we will assume that we are dealing with the deliberate disclosure of this information and not with accidental infiltration of information to a wide audience (in such situation the information would no longer be inside). RB and probably other undisclosed people will be secondary insiders which is illustrated on the Fig. 2.

We can consider at least two ways using existing models of propagation of inside information $[2,10]$. In the first case, people use information for an infinitely long time, i.e., even if they do not use it immediately on the same day, they can use it on the next day until it is disclosed. In the second case, we assume that people use inside information to complete the transaction on the day of obtaining this information.

In order to describe people who know at the moment $t$, one can use the following function

$$
L_{t}=N_{1} N_{2}\left(1-(1-P)^{t}\right)
$$

where $N_{1}$ is the number of people inside the company who have information, $N_{2}$ denotes the number of trusted people associated with one person from within the company, and $P$ is the probability of transferring information from inside the company to a trusted person (secondary insider). 
Let us assume that the secondary insider performs the transaction based on inside information with probability $P(Z)$, and at the moment $t$ the number of these transactions is $Z(t)$. The case for $t=1$ it is giben by:

$$
\begin{aligned}
& Z(1)=L_{1} P_{Z}=N_{1} N_{2} P_{Z}\left(1-(1-P)^{1}\right)= \\
& N_{1} N_{2} P_{Z} P .
\end{aligned}
$$

One can assume that people who at the moment $t=1$ do not perform the transaction, they may try a second time at $t=2$. Therefore,

$$
\begin{aligned}
& Z(2)=\left(L_{2}-L_{1} P_{Z}\right) P_{Z}=N_{1} N_{2} \\
& \times\left[\left(1-(1-P)^{2}\right) P_{Z}-\left(1-(1-P)^{1}\right) P_{Z}^{2}\right] .
\end{aligned}
$$

After some algebra one obtains the simpler equation for the moment $t=2$, namely:

$$
Z(2)=N_{1} N_{2} P_{Z} P\left(2-P-P_{Z}\right) \text {. }
$$

The checking whether at the moment $t=2$ we can have more transactions than at the moment $t=1$ indicates that

$$
Z(2)>Z(1) \text { and } 2-P-P_{z}>1,
$$

and one can expect that the maximum beyond the moment $t=1$ if

$$
P+P_{z}<1 \text {. }
$$

If the sum of the probabilities is greater than 1 then the maximum will remain at the moment $t=1$.

This is a significant result. Realize that if we deal with a shift in the maximum number of transactions beyond the moment $t=1$, it might mean that the probabilities of both the use and the transfer are low (both individually and their sum).

Again, assuming that people who performed transactions at $t=1$ or at $t=2$ will not make transactions, then for the moment $t=3$ the equation can be written as follows:

$$
\begin{gathered}
Z(3)=\left[L_{3}-Z(2)-Z(1)\right] P_{z}= \\
{\left[L_{3}-\left(L_{2}-L_{1} P_{z}\right) P_{z}-L_{1} P_{z}\right] P_{z},} \\
Z(3)=P_{z}\left[L_{3}-L_{2} P_{z}+\left(P_{z}-1\right) P_{z} L_{1}\right] .
\end{gathered}
$$

After some modifications, we obtain:

$$
\begin{aligned}
& Z(3)=N_{1} N_{2} P_{z} P \\
& \quad \times\left[P^{2}+\left(P_{z}-3\right) P+\left(P_{z}^{2}-3 P_{z}+3\right)\right] .
\end{aligned}
$$

Next, for the moment $t=4$, the equation can be written as:

$$
Z(4)=\left[L_{4}-Z(3)-Z(2)-Z(1)\right] P_{z},
$$

and simplified by substituting formulas for $Z(3)$, $Z(2)$ and $Z(1)$. Therefore,

$$
\begin{aligned}
& Z(4)=\left[L_{4}-P_{z}\left(L_{3}-L_{2} P_{z}+\left(P_{z}-1\right) P_{z} L_{1}\right)\right. \\
& \left.-\left(L_{2}-L_{1} P_{z}\right) P_{z}-L_{1} P_{z}\right] P_{z}
\end{aligned}
$$

and its final form for the moment $t=4$ is:

$$
\begin{aligned}
& Z(4)=N_{1} N_{2} P_{z} P\left[-P^{3}+\left(4-P_{z}\right) P^{2}\right. \\
& \left.\quad+\left(-P_{z}^{2}+4 P-6\right) P+\left(P_{z}^{3}+2 P_{z}^{2}-6 P_{z}+4\right)\right]
\end{aligned}
$$

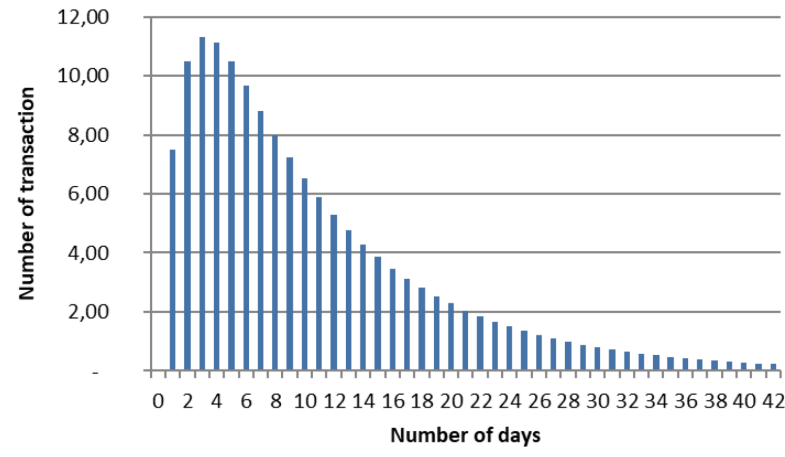

Fig. 3. Number of transactions as a function of time $Z(t)$ for $N_{1}=30, N_{2}=5, P=20 \%$ and $P_{Z}=50 \%$ - numerical simulations.

In the first case (infinite time of information use), the formula for the number of transactions is not analytically saved. On the basis of numerical simulations, it can be seen, however, that the maximum of the function falls between $t=2$ and $t=3$ (Fig. 3).

In the second case (limited time of using information to perform the transaction), the $Z(t)$ function can be written with an analytical formula [2]

$$
Z(t)=N_{1} N_{2} P_{z} P(1-P)^{t-1},
$$$$
\text { or }
$$$$
Z(t)=Z(1)(1-P)^{t-1}
$$

As this form shows that this function for $P<1$ reaches its maximum at $t=1$, i.e., on the first day. The value of this maximum is

$$
Z(1)=N_{1} N_{2} P_{Z} P \text {. }
$$

\section{Comparison of models with data}

In the case of Drewex, it can be clearly seen that only on the days marked with 1,2 and 3 , the number of transactions significantly exceeds the median value of the transaction. The maximum number of transactions is reached on the second day. In the following days the number of transactions decreases significantly (Fig. 4).

While the first day is easy to interpret as the day of disclosure of inside information, the second day is a day when several phenomena could overlap at the same time: further disclosure of inside information and investors' reaction to the increased volume on the security.

It can be seen at the same time, however, that the sharp increase in the company's share price was only related to the first day of the increased number of transactions. The second day of the increased transaction volume (despite the fact that the number of transactions has doubled) does not affect the increase in the share price. On the following days the price of shares decreases although in such a short time it does not return to the original price but to a new level of equilibrium (Fig. 5). 


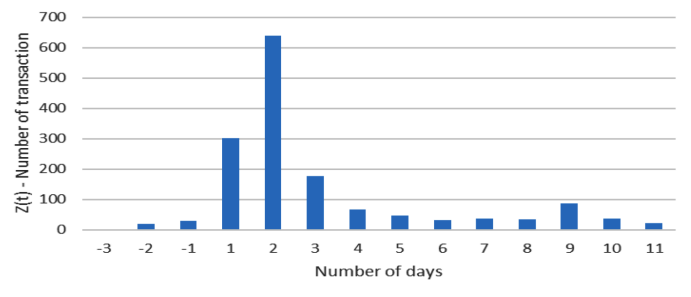

Fig. 4. Number of Drewex transactions from 21.10 .2010 (the minus third day) through 26.10.2010 (the first day) - proven use of inside information until 10.11.2010 (the eleventh day).

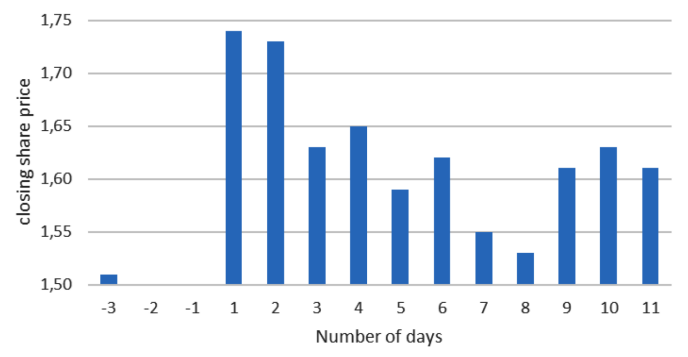

Fig. 5. Closing share price of Drewex transactions from 21.10.2010 (the minus third day) through 26.10.2010 (the first day) — proven use of inside information until 10.11.2010 (the eleventh day).

By differentiating (13) with respect to time and looking for zero spots for the derivative we get:

$$
\begin{aligned}
& \frac{\mathrm{d} Z(t)}{\mathrm{d} t}=(t-1) N_{1} N_{2} P_{z} P(1-P)^{t-2} \\
& 0=(t-1) N_{1} N_{2} P_{z} P(1-P)^{t-2}
\end{aligned}
$$

As this formula shows, this function for $P<1$ reaches its maximum at the point $t=1$, i.e., on the first day. The value of this maximum is

$$
Z(1)=N_{1} N_{2} P_{Z} P \text {. }
$$

Assuming that on the basis of both of the above information (significant impact on the price and a significant jump in the number of transactions) the disclosure of inside information took place on the first day, the probability $(P)$ of disclosing inside information can be calculated using the transformed formula:

$$
P=1-\left(\frac{Z(n)}{Z(1)}\right)^{1 /(n-1)} .
$$

Based on the data from the third day (176 transactions) and the first day (302 transactions) (day two shows slightly fewer transactions but additional phenomena may have occurred, so we decided to calculate it for day three), we obtain the value $P=0.70$. The probability of providing inside information was therefore as much as $70 \%$.

\section{Conclusions}

The above considerations prove that a significant increase in transaction volume is a better indicator of the likely insider trading (the use of inside information to perform a stock exchange transaction) than a price change alone. The retention of the number of transactions in this case was in line with the proposed model and the above considerations show that the simultaneous occurrence of an increased volume and price changes without the occurrence of other disturbing factors (e.g., earlier company reports) allows to suspect the occurrence of additional factors disturbing the state of perfect competition. One of such factors may be insider trading. Our limited time model showed that the probability of insider trading in Drewex SA shares was $70 \%$. This means that, in addition to the CEO of Calatrava Capital (convicted), there were probably other people who should have been also convicted for insider trading in this case. Going further, it can be concluded that the small number of proven cases of insider trading (with court judgments) does not mean that there were actually few such real cases. We hope that the widespread use of our model will improve the effectiveness of detection and prosecution of insider trading.

\section{References}

[1] C.B. Martysz, Manipulacje instrumentami finansowymi i insider trading, Analiza prawno-ekonomiczna, Wolters Kluwer, Warszawa 2015 (in Polish).

[2] A. Jakimowicz, A.A. Baklarz, K. Smulska Acta Phys. Pol. A 133, 1394 (2018).

[3] L. Harris, Trading and Exchanges, Oxford University Press, 2002.

[4] Regulation (EU) no 596/2014 of the European Parliament and of the Council of 16 April 2014 (MAR Regulation).

[5] A. Stokłosa, S. Syp, MAR Rozporzadzenie Parlamentu Europejskiego I Rady w sprawie nadużyć na rynku. Komentarz, Wolters Kluwer, Warszawa 2017 (in Polish).

[6] Annual reports of the Polish Financial Supervision Authority (KNF) and the Polish Securities and Stock Exchange Commission (KPWiG) from 2002-2018.

[7] P. Augustin, B. Brenner, M.G. Subrahmanyam, "Informed Options Trading prior to M\&A Announcements: Insider Trading?", NY University — L.N. Stern School of Business working papers, 2014.

[8] L. Meulbroek, J. Finance 47, 1549 (1992).

[9] Judgment of the District Court for Warszawa Wola in Warszawa at the Fourth Criminal Division of April 27, 2018, IV K 275/17 (in Polish).

[10] A.A. Baklarz, unpublished Ph.D. Thesis "Identification of the effects of disclosing inside information to investors on the Warsaw Stock Exchange", 2018. 